University of Wollongong

Research Online

Faculty of Business - Papers (Archive)

Faculty of Business and Law

2013

Development of a market orientation research agenda for the nonprofit sector

Paul Chad

University of Wollongong, pchad@uow.edu.au

Elias Kyriazis

University of Wollongong, kelias@uow.edu.au

Judy M. Motion

University Of New South Wales, jmotion@uow.edu.au

Follow this and additional works at: https://ro.uow.edu.au/buspapers

Part of the Business Commons

Research Online is the open access institutional repository for the University of Wollongong. For further information contact the UOW Library: research-pubs@uow.edu.au 


\title{
Development of a market orientation research agenda for the nonprofit sector
}

\begin{abstract}
Market orientation is the overarching framework by which practitioners and academics make sense of the interplay between customers, competition, stakeholders, and the organization within the commercial forprofit arena and is the way the marketing concept is put into practice. Many academics have argued that market orientation would also benefit nonprofit organizations by generating more funds in an increasingly competitive environment. The purpose of this article is to conduct a systematic review of market orientation, identify gaps, and develop a research agenda for market orientation research within the underresearched nonprofit sector. This research agenda highlights the structural, human resource, and cultural challenges nonprofit organizations face if they decide to adopt a market orientation, and the need to develop a praxis framework currently missing from the literature. The article offers suggestions for researchers to extend the concept of market orientation from the commercial for-profit into the nonprofit arena.
\end{abstract}

\section{Keywords}

research, agenda, market, nonprofit, orientation, sector, development

Disciplines

Business

Publication Details

Chad, P., Kyriazis, E. \& Motion, J. M. (2013). Development of a market orientation research agenda for the nonprofit sector. Journal of Nonprofit and Public Sector Marketing, 25 (1), 1-27. 


\title{
Development of a Market Orientation Research Agenda for the Nonprofit Sector.
}

\author{
PAUL CHAD \\ Centre for Research in Socially Responsible Marketing \\ University of Wollongong, Wollongong, New South Wales, Australia \\ ELIAS KYRIAZIS \\ Centre for Research in Socially Responsible Marketing \\ University of Wollongong, Wollongong, New South Wales, Australia \\ JUDY MOTION \\ University of New South Wales, Sydney, New South Wales, Australia
}

Address correspondence to Dr Paul Chad, PhD, School of Management \& Marketing, University of Wollongong, Northfields Ave., Wollongong, NSW, 2500, Australia.

E-mail: pchad@uow.edu.au 


\title{
Development of a Market Orientation Research Agenda for the Nonprofit Sector.
}

\begin{abstract}
Market orientation is the overarching framework by which practitioners and academics make sense of the interplay between customers, competition, stakeholders and the organization within the commercial for-profit arena and is the way the marketing concept is put into practice. Many academics have argued that market orientation would also benefit nonprofit organizations by generating more funds in an increasingly competitive environment. The purpose of this paper is to conduct a systematic review of market orientation, identify gaps, and develop a research agenda for market orientation research within the under-researched nonprofit sector. This research agenda highlights the structural, human resource and cultural challenges nonprofit organizations face if they decide to adopt a market orientation, and the need to develop a praxis framework currently missing from the literature. The paper offers suggestions for researchers to extend the concept of market orientation from the commercial for-profit into the nonprofit arena.
\end{abstract}

Keywords: Market orientation, societal orientation, marketing, charity, nonprofit, not-for-profit, research agenda

Running head: Market orientation research agenda for NPOs 


\section{INTRODUCTION}

Market orientation is considered to be the operationalization of the marketing concept within organizations. Whilst firms may use marketing tools such as advertising and promotion in their daily activities, the firm may not be seen to be market oriented. Market oriented firms focus clearly on the needs of their customers and align organizational focus, processes and structure to meet customer needs (Kohli \& Jaworski, 1990; Narver \& Slater, 1990). With the successful adoption of market orientation in the commercial for-profit sector resulting in improved organizational performance (Day, 1994; Kohli \& Jaworski, 1990; Narver \& Slater, 1990), it was natural that the emergent nonprofit sector would be viewed as a suitable beneficiary for the lessons already learned. Many academics (for example, Barrett, Balloun, \& Weinstein, 2005; Kara, Spillan, \& DeShields Jr, 2004; Kinnell \& MacDougall, 1997; Wood, Bhuian, \& Kiecker, 2000) were quick to argue that a market orientation would provide benefits for NPOs (nonprofit organizations) such as charities and non-government organizations that were entering a highly competitive environment for funding and revenue generation and feeling pressure to provide improved service delivery.

Emerging empirical evidence supports the use of market orientation by NPOs. For

example, Vázquez, Álvarez and Santos (2002) showed that market orientation had a positive effect on the outcomes of NPOs. Gainer and Padanyi (2002, p. 182) examined arts organizations in Canada and determined that a market-oriented culture 'predicted a growth in resources and higher levels of customer satisfaction' and in further research Gainer and Padanyi (2005) examined the link between market orientation and culture in Canadian NPOs (social service, community support and arts) and concluded that a client oriented culture and behaviour was important for organizational performance. 
The dominant view amongst NPO researchers (for example, Warnaby \& Finney, 2005) is that market orientation is relevant to the nonprofit sector - in some form or another, but cannot simply be transferred from the for-profit arena and that the sector lags in its introduction and usage. The increasing competition within the nonprofit sector makes an introduction of market orientation an imperative sooner rather than later. Indeed, within Australia for example, 'much of the sector is still operating in a survival framework ...' (Nonprofit Australia, 2006) and is neither ready 'nor able to meet the challenges of the 21st century without major transformation ...' (Nonprofit Australia, n.d.).

Significantly, Andreasen and Kotler (2003, p. 11) contend that 'marketing and marketing skills inevitably must play a more central role’ within NPOs. Seymour, Gilbert and Kolsaker (2006, p. 151) do however indicate that only recently has the issue of market orientation 'attracted the interest of charities who, facing increasing competition and environmental complexity, are seeking differentiation and competitive advantage'. Complicating matters is that the scope and nature of marketing as a discipline is misunderstood with the perception of many NPOs that 'marketing' consists simply of the occasional promotion, advertising and selling (Brady \& Johnson, 1999; Kolb 2008) rather than addressing needs and wants via the marketing concept.

The key conclusion from our systematic review of the literature is that application of the marketing concept, operationalized by introduction of a market orientation, is a relatively underresearched area within the nonprofit sector. What research has been conducted in the nonprofit context, particularly in relation to frameworks of market orientation, has been somewhat broad and has taken a 'blanket' approach attempting to cover all forms of NPOs - or has only explored basic aspects of market orientation in specific nonprofit sub-sectors such as charities. 
This paper thus has three key research objectives, firstly, to review and examine the market orientation framework and associated research. Secondly, justify the relevance of market orientation in some form for the nonprofit sector. Thirdly, as the majority of market orientation research has been conducted in the commercial for-profit sector, given the transferability of market orientation in some form to the nonprofit sector whose raison d'être is different to forprofit organizations, we develop a market orientation research agenda for the nonprofit sector an important contribution to the literature. Our systematic review of literature reinforces the comments of Modi and Mishra (2010, p. 565) who recently stated that '[m]arket orientation in the for-profit sector is one of the most researched fields in the marketing discipline. However, non-profit marketing as a whole and market orientation of NPOs in particular are largely underresearched areas'. To illustrate this, based upon our systematic review of the market orientation literature, we provide Table 1 showing the research 'intensity' to which various market orientation issues have been addressed in both for-profit and nonprofit contexts and indicate that $85 \%$ of market orientation papers reviewed related to the for-profit sector. This suggests scope to progress research of these issues in the nonprofit context given the strong support for the use of these concepts within the sector (for example, Kotler \& Lee, 2009; Lovelock, Patterson, \& Walker, 2004).

\section{INSERT TABLE 1 ABOUT HERE}

We contribute to the literature in two key ways, one, we reinforce that whilst market orientation in some form is relevant for the nonprofit sector, we identify various key knowledge gaps within existing literature. Second, we develop a comprehensive research agenda including 
highlighting a key need to progress development of a praxis framework for NPOs that captures the significant structural, human resource and cultural challenges that NPOs face if they decide to adopt a market orientation.

Our paper is organised into five main sections. First, we discuss the role and reason for NPOs and identify the key differences between for-profit and nonprofit organizations. Second, based upon our systematic review of the market orientation literature, we overview details of market orientation research including definitions and frameworks. Third, we discuss the application of market orientation to the nonprofit sector. Fourth, the broadening market orientation research is discussed within various sub-topics enabling identification of gaps in market orientation research - ' where the literature is now' (Macpherson \& Jones, 2010, p. 111) enabling our identification and development of market orientation research questions within the nonprofit sector. We conclude with a challenge to market orientation researchers to extend their research into the nonprofit sector based upon our proposed research agenda - for the benefit of society.

\section{THE ROLE AND REASON FOR NONPROFIT ORGANIZATIONS}

The nonprofit sector, sometimes referred to as the voluntary sector or the third sector, can be regarded as providing six types of roles within society, namely service provision, innovation, individual expression, social capital creation, political advocacy and citizen engagement (Moulton \& Eckerd, 2012). Similarly, the International Classification of Non Profit Organizations (ICNPO) aims to classify NPOs based upon their primary field of activity and provides twelve activity groups - e.g. 'culture and recreation', 'health', 'social services' and 'environment' (Australian Bureau of Statistics, 2009). A weakness of this classification however 
is that various NPOs actually operate across a range of fields, thus only the primary field of operation is captured in the classification. Given the wide range of roles and activities, the nonprofit sector is thus extremely diverse.

There are various theories regarding why NPOs exist. Based upon examination of the US nonprofit sector, Rosenbaum (1984) suggests NPOs have progressed through four stages - an initial 'voluntary model' whereby volunteers joined together to provide services not provided by government, 'philanthropic patronage' whereby wealthy people provided money to fund various causes, followed by a 'rights and entitlements' stage whereby government supported a range of programs as various groups considered they were entitled to a proportion of public tax funds. The fourth stage suggested by Rosenbaum is a 'competitive/market stage' because NPOs cannot gain funds from the traditional sources of the past. Offering a slightly differing perspective is Salamon (1987) who refers to 'market failure/government failure' and 'contract failure'. Where products are not available from the private sector (market failure), these products can be provided by government. However, if government chooses not to provide these products (government failure), NPOs may step in and provide such goods and services. Contract failure can occur, often when the purchaser is not the consumer (Hansmann, 1980), when a for-profit organization may not be trusted, thus NPOs are seen as more trustworthy to deliver the product. Salamon (1987) also considers 'voluntary failure’ can occur, typically due to a struggle for funds by the nonprofit/voluntary sector, and subsequently suggests 'third-party government' whereby government provides funds to the voluntary sector who are in a better position than government to deliver goods and services - thus creating a win-win situation for both the voluntary sector and government. This is supported by Luksetich (2008) who indicates that a key reason why government may utilise NPOs to deliver services is based upon the lower service delivery costs 
of well-operated NPOs. More recently, Andreasen and Kotler (2008) have offered similar reasons to Salamon for NPO existence - that NPOs provide services not offered by government (public goods theory), some people consider that for-profit organizations cannot be trusted to provide some products (contract failure theory), and government decides what NPOs provide (subsidy theory).

A large number of NPOs exist and not only play a vital role within society, but are also an important component of the economy in many countries. For example, the USA is home to 1.4 million NPOs (National Center For Charitable Statistics, 2010), the largest number of any country. Of these 1.4 million NPOs within the USA, 1 million are registered as charities, and employment within these charities represents over $10 \%$ of the overall US workforce and is thus an important source of employment (Salamon \& Sokolowski, 2006).

Whilst NPOs can be seen as a response to some form of market failure (Hansmann 1980), they can be regarded as having 'a market for resource acquisition and a market for resource allocation' (Sargeant, 2009, p. 57). NPOs compete in the resource acquisition market for revenue (government funds, private and corporate donations) and labour (both volunteer and paid). NPOs also compete in the resource allocation market whereby potential clients/customers may have a choice of NPO providers. The diverse nature of NPOs can however affect the nature and level of competition within these markets. For example, government is more likely to provide funds to NPOs operating within the 'social services' sub-sector than to NPOs operating within the 'business and professional associations' sub-sector. Also, potential clients/customers are likely to be more selective in the 'culture and recreation' sub-sector than in the 'social services' subsector where clients/customers are likely to be happy to receive assistance from any organizations and not compare potential providers. 


\section{DIFFERENCES BETWEEN FOR-PROFIT AND NONPROFIT ORGANIZATIONS}

Relative to for-profit organizations, NPOs 'are more complex' (Anheier, 2000, p. 16). Whilst adopting a market orientation is appropriate for NPOs, there are unique differences between for-profit organizations and NPOs that need to be taken into consideration. Table 2 contains an overview of the differences. These differences need to be appreciated by academics and practitioners when considering the transfer of market orientation knowledge gained in the for-profit arena to the nonprofit context. A characteristic of many NPOs is use of, and sometimes reliance upon volunteers.

\section{INSERT TABLE 2 ABOUT HERE}

\section{MARKET ORIENTATION}

Market orientation draws its origins from the marketing concept which suggested businesses should focus on customers, satisfy their needs, and appreciate the relevance of competitive advantage (Drucker, 1954; Levitt, 1960). As the growth and influence of marketing departments within organizations expanded, there was a clear need for a managerial framework to define the field and guide strategy as well as decision-making regarding the operationalisation of the marketing concept within the organization. Several authors responded to this research need, notably Shapiro (1988) with his seminal work "What the Hell is Market Oriented?” where he defined it as an organizational decision-making process consisting of information gathering, organization-wide decision making and effective execution of decisions. Key tenets of a MO include: organizationwide generation of market intelligence, dissemination of the intelligence 
across departments, and organization-wide responsiveness to it, and the need for positive interdepartmental dynamics that facilitate cross-functional market intelligence transfer and avoid the arising of conflict. (Kohli \& Jaworski, 1990, 1993; Narver \& Slater, 1990). Of these studies, Narver and Slater were the first to show 'a substantial positive effect of a market orientation on profitability' (Narver \& Slater, 1990, p. 20) for both commodity and non-commodity businesses. This study, alongside Kohli and Jaworski's (1990) paper, are considered the theoretical foundations for market orientation.

In an attempt to draw together the various views of market orientation that had evolved from the seminal papers, Lafferty and Hult’s (2001) synthesis of these contemporary market orientation perspectives highlight four common areas of agreement within the field. The metaanalysis of Lafferty and Hult (2001) highlighted that whilst the various definitions of market orientation were either cultural or managerial focussed, there was in essence a degree of commonality which assisted academics to clarify the key aspects of market orientation, namely (1) an emphasis on customers, (2) the importance of information, (3) inter-functional coordination, and (4) taking action.

Market orientation is considered the key organizational orientation that contributes to performance (Grinstein, 2008). Via a longitudinal survey, the positive affect of market orientation in both the short-term and long-term was recently confirmed by Kumar, Jones, Venkatesan and Leone (2011) who also considered that a market orientation is a necessity for organizations in the dynamic business environment we have where economic slowdowns, growth, competitive intensity, mergers and acquisitions, globalization, and rapid fire technological innovations require managers to be able to sense and respond to market changes quickly. 


\section{APPLICATION OF MARKET ORIENTATION TO THE NONPROFIT SECTOR}

The previous section outlined the framework of market orientation in the for-profit sector and its promise of improved organizational outcomes. Balabanis, Stables and Phillips (1997, p. 583) regarded the 'debate about the validity of extending the marketing concept beyond the domain of the classical commercial organization seems to have been settled'. Similarly, based upon metaanalysis of eleven papers examining MO in NPOs, MO was positively overwhelmingly found to have a beneficial affect upon performance (Shoham et al. 2005). Despite the relevance of MO to the NPO sector, direct transference of existing MO knowledge from the for-profit sector is not straight-forward due to the differences between for-profit organisations and NPOs. For an equivalent size, NPOs can be regarded as more complex operations than a for-profit organisation, thus 'ready-made management models carried over from the business world' (Anheier 2000, p. 8) are not appropriate for NPOs without modification. There are also 'unique challenges of managing nonprofit organizations' (Silverman \& Taliento 2006, p. 37) as the 'ethos that drives their application can be radically different' (Sargeant 2009, p. 3).

Given the perceived differences between for-profit and nonprofit organizations, various researchers have proposed 'societal orientation' models for the nonprofit sector that are basically modifications of the seminal for-profit models. Combining aspects of the Narver and Slater (1990) and Kohli and Jaworski (1990) for-profit models, Sargeant, Liao and Foreman (Liao, Foreman, \& Sargeant, 2001; Sargeant, Foreman, \& Liao, 2002) added a new component titled 'collaboration' as some competitors within the nonprofit sector may work together to develop mutually beneficial synergies, and 'customer' was renamed 'stakeholder' to reflect a broader definition of customer in the nonprofit context. The Kohli and Jaworski (1990) for-profit model 
was modified by Gonzalez, Vijande and Casielles (2002, p. 63) who divided customers into donors and beneficiaries. More recently, Duque-Zuluaga and Schneider (2008) modified the Narver and Slater (1990) for-profit model by splitting 'customer' into three subsets beneficiary/recipient, donor, volunteer/employee and adding a new element encompassing learning and social entrepreneurship.

\section{A MARKET ORIENTATION RESEARCH AGENDA FOR THE NONPROFIT SECTOR}

To give the reader an understanding of key market orientation issues, based upon our systematic review of the literature we categorize and review the important market orientation research subtopics and also identify the sparse nonprofit research in many of these areas. For each of these sub-topics we then develop nonprofit research questions to guide future research in these underresearched but important areas.

1. Resistance to the implementation of market orientation - establishing legitimacy

2. Market orientation measurement and the market orientation/performance link

3. Responsiveness to the external environment (customers and competition)

4. Organizational factors (size of firm, age/evolution of firm)

5. Market orientation and innovation/entrepreneurialism

6. Controversies over definition and scope of market orientation

\section{A. For-profit: Resistance to the implementation of market orientation - establishing}

\section{legitimacy}

The actual implementation of the marketing concept is not considered straight-forward and has been hindered in some instances due to organizations having difficulty developing customer 
focus due to barriers such as an incomplete understanding of the marketing concept, conflict between short and long-term goals, top managements' own values and also failure to define markets in terms of customers (Webster Jr, 1988).

Managers who wished to introduce market orientation into their organization often faced resistance from employees as well as system-focused barriers (Harris \& Piercy, 1999). Various barriers/impediments to development of market orientation have been identified in the literature (Bisp, 1999; Harris, 1996, 1998, 2000; Harris \& Watkins, 1998, Kennedy, Goolsby, \& Arnould, 2003; Kippenberger, 1998; Mason \& Harris, 2005; Wong, Saunders, \& Doyle, 1989; Savitt, 2001). Typical barriers include management beliefs, short-term focus, difficulty in changing traditional thinking, organizational structure, apathy, self-interest of staff, lack of co-operation between functional units and lack of understanding of potential benefits.

In a meta-analysis, Kirca, Jayachandran and Bearden (2005, p. 36) determined 'that internal processes have a greater influence than organizational structure variables' on the introduction of market orientation. Thus, internal marketing is important (Lings \& Greenley, 2005; Naude, Desai, \& Murphy, 2003). Various barriers can be addressed by managers utilising participative and supportive leadership styles (Börjesson \& Dahlsten, 2004; Harris \& Ogbonna, 2001) with Lam, Kraus and Ahearne (2010, p. 61) suggesting that top managers need to act as role models to both middle managers and 'work-group expert peers' who in turn become role models to frontline employees to enable diffusion of market orientation through organizations.

To successfully introduce a market orientation involves removing the barriers and utilising a staged process of organizational change. Gebhardt, Carpenter and Sherry Jr (2006) suggested a four-stage model for the process of introducing market orientation, namely, initiation, reconstitution, institutionalisation and maintenance whilst Beverland and Lindgreen 
(2007) examined the successful implementation of market orientation introduction utilising Lewin’s (1951) three stage model of unfreezing, movement and freezing.

In summary, implementing a market orientation requires removal of barriers, and a staged approach to introduction. Based on a review of literature, van Raaij and Stoelhorst (2008) regard the key antecedents of market orientation to be - structure, process design, information systems, reward systems, leadership, behavioural norms and values, competence management.

\section{B. NPO Resistance to the implementation of market orientation - establishing legitimacy}

In the nonprofit context, the sparse research into barriers to introducing market orientation include Gainer and Padanyi (2005) who examined Canadian nonprofit social service, community and arts organizations and determined that employee culture was a significant determinant in improving market orientation and hence performance. Likewise, developing an internal market orientation amongst employees first has been identified as beneficial prior to progressing to introducing an external market orientation within the nonprofit sector (Cano and Sams, 2009; Murray, Yong Gao, \& Kotabe, 2011) and employee resistance can be overcome via strong management communication to employees of the benefits of market orientation for their service recipient clients (Chad, Kyriazis, \& Motion, 2010).

Reviewing the barriers to market orientation adoption, it is clear that the first thing that management have to clearly convey to the organization is a credible reason to introduce a market orientation. Many nonprofit employees do not understand the rationale of the marketing concept, and when they hear the word 'marketing' often think of tools such as promotion and advertising 
- which they regard as expenses and taking away valuable money that could be used for service delivery.

Little is known of the processes by which use of a market orientation can be 'sold' to employees and resistance to its use overcome. Accordingly we propose research addressing the following research question:

RQ1: How does the top management of nonprofit organizations legitimise the adoption of 'marketing' and push for a market orientation within their organization?

Once top management have made the decision to go ahead with progressing use of market orientation, how do they accomplish this? Lam, Krause and Ahearne (2010) suggested a social learning approach to the implementation of market orientation in the commercial, forprofit sector using middle management and envoys (influential employees) as a successful strategy. Within the nonprofit context very little is known about this process. Current research tends to examine aspects of market orientation in a 'static' situation. Whilst barriers to introducing market orientation have been identified (albeit in a for-profit context), there is very little, if any research that has examined the manner in which market orientation is, or can actually be introduced successfully into a nonprofit organization. Indeed, research examining the actual process by which NPOs have actually successfully introduced market orientation is nonexistent. This therefore leads to our next research question:

RQ2: How do nonprofit organizational executives successfully introduce market orientation? 
Related to this is what do NPOs actually need to become more market oriented? This is a capabilities and resource issue. From a resources perspective, whilst many NPOs take pride from relying upon volunteer labour and donations, this can result in inefficient operations (Lewis 1995) and amateur instead of professional service provision (Salamon, 1987). How do NPOs who wish to become more market oriented gain the appropriate capabilities? Does the organization with traditionally volunteer labour and possibly little if any marketing capabilities buy in the professional skills, utilise consultants or up-skill existing employees? Hence, the next research question:

RQ3: What new capabilities does a nonprofit organization require to become market oriented and how does the organization gain these capabilities?

The above three research questions can be utilised within each sub-sector of the overall nonprofit sector. Extant market orientation (including the societal orientation) literature within the nonprofit context typically involves assessing the level of market orientation within organizations at specific points in time, or develops conceptual models regarding appropriate frameworks for a market orientation or a societal orientation. This literature has been spread somewhat thinly across the gamut of NPOs. Significantly, there is no existing marketing literature examining change within NPOs as market orientation is introduced. By examining research questions $R Q 1, R Q 2 \& R Q 3$ in real situations would enable combining these learnings to assist in the development of a praxis framework to guide managerial action to successfully introduce market orientation. This would be a significant advancement of knowledge. Given the 
required interplay between all sections of an organization in enabling market orientation to succeed, such a framework should indicate how each section of an organization can assist and become involved in introducing a market organization. This would be a valuable transdisciplinary contribution across the market orientation, nonprofit and change management areas of research. Thus:

RQ4: What is an appropriate praxis framework to assist managers of organizations within each sub-sector of the nonprofit sector to introduce market orientation?

Associated with this issue of how do managers introduce market orientation successfully into the NPO, a review of the literature has not identified any research specifically related to examination of the introduction of market orientation into an organization and its subsequent affects on employees. This is perceived as a key issue, particularly within the charity sub-sector for example, where employees have traditionally eschewed the business methods of for-profit organizations and would be regarded as a key resistance to successful implementation of market orientation. This leads to a further research opportunity, namely:

RQ5: How does top management manage the change process and what is the effect of introduction of a market orientation upon nonprofit organizational employees?

\section{A. For-profit : Market orientation measurement and the market orientation/performance} link 
This research area focussed on providing hard evidence for the top management of organizations that adopting a market orientation was actually a sound business strategy and worth the considerable effort in time and resources that such a change process would entail. Inevitably, ensuring that market orientation and its effect on business performance was accurately measured become an important focus for many researchers. The positive affect of market orientation upon business performance is the underlying reason why development of a market orientation is regarded as an appropriate goal for organizations. Various scales to measure market orientation and business performance were developed (for example, Deshpande, Farley, \& Webster, 1993; Kohli, Jaworski, \& Kumar, 1993: Narver \& Slater, 1990).

\section{B. NPO: Market orientation measurement and the market orientation/performance link}

In the nonprofit context, Vázquez, Álvarez and Santos (2002) developed a specific market orientation measurement scale. Based upon the Kohli and Jaworski (1990) definition of market orientation, they expanded 'marketing intelligence' to include beneficiaries, donors, competitive alternatives and potential collaborators. Items were selected from existing scales developed in the for-profit arena and customised for the nonprofit sector resulting in a 31 item scale containing 13 items for intelligence generation, eight items for intelligence dissemination and ten items for responsiveness.

Examples of the research regarding the linkage of market orientation to nonprofit organizational performance includes Sehorn (1995) who found a positive link between market orientation and business performance in community service organizations, and Jones (2000) who examined market orientation within UK opera companies. The majority of market orientation research has examined for-profit organizations that are profit driven commercial enterprises with 
typical goals of profitability and shareholder return. Whilst long-term success is the goal of most large organizations, Blankson and Stokes (2002) found that for small organizations, profitability was important, but long-term objectives were less important. Likewise, the goals of NPOs can vary dramatically from those of large, for-profit organizations. Whilst goals of for-profit organizations tend to be financially related, goals for NPOs (as well as financial goals related to donation levels) typically include levels of volunteer recruitment and level of service delivery to service recipient clients. Gainer and Padanyi (2002) considered there was sometimes suspicion about using business practices in NPOs as they may divert the organization away from its traditional mission and values - a clash of goals. Given the unique nature of NPOs, Padanyi and Gainer (2004) examined the issue of 'multiple constituencies' (client and donor) and divided NPOs into four clusters - client oriented (high/low) and funder oriented (high/low).

This leads to three key issues. Are all the various dimensions of market orientation equally relevant to each of the nonprofit sub-sectors. Also, how should performance be measured? Thus:

RQ6: Which key dimensions of market orientation are relevant to each sub-sector of the nonprofit sector and to what extent?

RQ7: What is an appropriate market / societal orientation measurement scale for each sub-sector of the nonprofit sector?

RQ8: How should each sub-sector of the nonprofit sector measure performance? 


\section{A. For-profit : Responsiveness to the external environment (customers and competition)}

This research area relates to the organizational capabilities that affect responsiveness to customers and competitors through information gathering and dissemination. Organization ‘capability’ was examined in the seminal paper by Day (1994). Capabilities were defined by Day (1994, p. 38) to be 'complex bundles of skills and accumulated knowledge, exercised through organizational processes, that enable firms to coordinate activities and make use of their assets'. Day (1994) contends that organizations that are better equipped to respond to the market and can anticipate changes in the marketplace will have superior profitability via long-run competitive advantage. Similarly, in capturing the external environment for new products, Pelham (2000, p. 48) considers the capability to provide 'fast response to negative customer satisfaction information, strategies based on creating value for customers, immediate response to competitive challenges, and fast detection of changes in customer product preferences' are required to achieve a high level of market orientation. Baker and Sinkula (2005) also consider top management need to ensure appropriate organizational capabilities exist to examine customer needs and competitor movements.

The ability to gain relevant intelligence is the crux of market orientation. The process of actually gaining competitive intelligence has been analysed by Jaworski, Macinnis and Kohli (2002) who consider there are three distinct phases to the competitive intelligence generation process - organising to get intelligence, searching for intelligence and then sense-making of intelligence. The importance of involving the entire organization in intelligence generation was considered by Cravens, Piercy and Prentice (2000, p. 374) who caution that 'market sensing' should involve not only management, but those who 'are close to the market', such as sales staff. 
Darroch and McNaughton (2003) took the intelligence issue a step further, and consider knowledge-management capability as a distinctive capability for sustainable competitive advantage and suggest market orientation to be a subset of knowledge-management orientation. Javalgi, Martin and Young (2006) examined the role of market research in assisting global firms improve market orientation and developed a framework linking international services marketing research to market orientation and CRM. They consider market research to be inextricably linked to providing an organization with relevant information to develop a market orientation.

\section{B. NPO: Responsiveness to the external environment (customers and competition)}

NPOs are traditionally regarded as having to struggle for resources, and hence capability to respond to the external environment. Market intelligence/knowledge is a key aspect of market orientation capabilities. In the nonprofit context, Martinsons and Hosley (1993, p. 40) casestudied a Hong Kong hospital and considered 'information requirements for marketing decisions in this not-for-profit organization are quite similar to those of profit-seeking enterprises’. Whilst many NPOs do not have formal market intelligence generation systems, many utilise a more cheaper form and use word-of-mouth and networking to gain valuable information (Chad, 2010).

Customers in the nonprofit context are extremely diverse and include revenue providers (government, corporate and individual donors, fee-for-service clients, service recipients), employees (including volunteers). Thus, NPOs have a more complex customer base and hence more diverse information requirements than for-profit organizations.

Competition is an interesting issue within the nonprofit sector. Whilst it may occur between NPOs in some sub-sectors for both resource acquisition and usage, it is perhaps not a 
key issue within the charity sub-sector in relation to 'service recipient' clients where collaboration between charities is preferred. One charity, if short of resources would refer a client to another charity, and/or collaborate on the best way to assist a mutual client. Competition is however a key issue between charities when attempting to gain resources such as revenue (e.g. competing for government grants and tenders) and volunteer labour. From a resource/capability perspective, organisations having tender writing capability and the best capability to deliver services may win government funding.

The issue of competition can result in a unique situation whereby other charities are seen as both collaborators and competitors, depending on the situation - revenue acquisition or service delivery. Whilst collaboration amongst NPOs can offer a win-win situation in specific situations (Osborne \& Murray, 2000), there is little research regarding why NPOs 'develop certain forms of collaboration instead of others' (Guo \& Acar, 2005, p. 342). Similarly, 'little is known’ about how NPOs manage relationships with various stakeholders (Balser \& McClusky, 2005, p. 300). This therefore leads to another research question:

RQ9: How does inter-organizational competition and collaboration affect the relationships between charities?

\section{A For profit : Organizational factors (size of firm, age/evolution of firm)}

As discussed above, capability is a key factor to enable an organization to develop a market orientation. Factors such as organizational size and age are also considered relevant factors in determining the level to which an organization can develop market orientation. In regards to age of an organization, Becherer, Halstead and Haynes (2001) suggest years of operation are not 
significant in regards to level of market orientation. However, Perry and Shao (2002) postulated that the relative importance to firms of market orientation may vary between existing and new firms within an industry due to differing capabilities. Likewise, Tang, Wang and Zhang (2005, p. 67) found that 'years in business are positively associated' with business performance. In support of this, Engelen, Brettel and Heinemann (2010) examined the effect of organizational life cycles on market orientation and also determined that older firms are more pre-disposed to market orientation.

In regards to size, there is conflicting research regarding the affect of organization size on market orientation within the for-profit sector. Liu (1995), Wijewardena and Cooray (1995) as well as Becherer, Halstead and Haynes (2001) suggest that market orientation increases with company size. Contrary to these views, being small can assist speed of implementation (Chen \& Hambrick, 1995) and may enhance the ability to exploit a market oriented organizational culture (Pelham \& Wilson, 1996). Also, Pelham (2000) found a negative relationship existed between firm size and market orientation. Opposing both these contrasting perspectives, size is considered irrelevant by other researchers (Blankson \& Cheng, 2005; Low 2005).

Whilst a market orientation is relevant for organizations of all sizes, including smaller organizations (Carson, 1985, 1990; Carson \& Gilmore, 2000), lack of sophisticated marketing is problematic for the smaller firms (Cromie 1991) and often dependent on management capability (Hogarth-Scott, Watson, \& Wilson, 1996; Liu, 1995) and resources (Fuller 1994; Gilmore, Carson, \& Grant 2001; Smith 1997). The perceived lack of resources within small and medium sized organizations can be overcome via collaboration (Beckett, 2005), networking (Gilmore, Carson, \& Grant, 2001; Terziovski, 2003) and use of University students (Ahmadi \& Helms, 1997; Brindley \& Ritchie, 2000; Sonfield, 1981) as a low-cost labour resource. 


\section{B NPO : Organizational factors (size of firm, age/evolution of firm)}

A similar conflict regarding whether there is a linkage between market orientation and organizational size exists in the nonprofit context. Seymour, Gilbert and Kolsaker (2006) found that smaller charities have the lowest level of market orientation, whereas Balabanis, Stables and Phillips (1997, p. 599) measured adoption of the marketing concept in the top 200 British charities and concluded 'that larger organizations were more reluctant or able to become market oriented'. More recently, however, Brady, Brace-Govan, Brennan and Conduit (2011) have identified a positive relationship between size and market orientation for nonprofit organizational performance measured in terms of fundraising success.

Existing market orientation research tends to suggest that larger organizations are more able to utilise market orientation to achieve improved performance. This may also be relevant for some of the nonprofit sub-sectors, but within the charity sub-sector, there is a view that the ideal size of a charity is when the organization no longer exists due to no more demand for the services of that charity. An alternative view is that larger charities have greater economies of scale in regards to service delivery and are therefore more effective in utilising scarce resources. Thus:

RQ10: Charity performance - Does size matter, and what is the ideal size for a charity?

Current research regarding the relationship between organizational age and level of market orientation within NPOs is mixed (for example, Balabanis, Stables, \& Phillips, 1997; Brady et al., 2011; Seymour et al., 2006). This may be due to greater awareness now amongst the 
top management of NPOs of the benefits of market orientation, resulting in both young and older organizations being just as likely to adopt market orientation. This is an issue that can be explored further:

RQ11: What is the likelihood of young organizations adopting a market orientation relative to older organizations within each of the nonprofit sub-sectors?

\section{A For profit : Market orientation and innovation/entrepreneurialism}

Various research suggests that innovation contributes to organizational success (Gatignon \& Xuereb, 1997; Kumar, Scheer, \& Kotler, 2000; Matear, Gray, \& Garrett, 2004; Tajeddini, Trueman, \& Larsen, 2006) and that an entrepreneurial style can positively affect organizational performance (Covin \& Slevin, 1988). There are however conflicting views regarding the linkage between market orientation and entrepreneurialism/innovation. For example, Bhaskaran (2006) considers market orientation and entrepreneurialism/innovation are positively linked, Mavondo, Chimhanzi and Stewart (2005) consider market orientation is an antecedent to innovation, whilst Deshpande and Farley (2004) suggest innovation/entrepreneurialism is not essential for success. Also, Matsuno, Mentzer and Ozsomer (2002) contend that entrepreneurialism/innovation by

itself negatively affects performance, and Matear, Osborne, Garrett and Gray (2002) regard innovation as separate to market orientation but necessary for effective firm performance.

A strong market orientation was found to be positively related to new product development and new product performance (Kyriakopoulos \& Moorman, 2004; Langerak, Hultink, \& Robben, 2004a, 2004b). Various studies suggesting that a learning organization is perhaps a higher level than market orientation have been conducted (Baker \& Sinkula, 1999a, 
1999b, 2002) and contend that a learning orientation resource increases ability to effectively utilise a market orientation (Farrell, 2000; McGuinness \& Morgan, 2005). In other words, a combination of market orientation, learning orientation and organizational change capability is required to ultimately improve business performance.

\section{B NPO : Market orientation and innovation/entrepreneurialism}

The relationship between market orientation and innovation/entrepreneurialism has been extensively explored within the for-profit sector, but has been sparsely explored within the nonprofit context. The nonprofit sector has historically not been renowned for innovation/entrepreneurialism. However, given the increased competition within the sector, there is scope for innovation/entrepreneurialism to greatly assist these organizations. It is considered 'that entrepreneurship has a legitimate role in non-profits and the work environment can be designed to enable various levels of entrepreneurship’ (Morris, Coombes, \& Schindehutte. 2007, p. 12). Indeed, Duque-Zuluaga and Schneider (2008) regard social entrepreneurship as a component of societal orientation. Mair and Marti (2006, p. 37) define social entrepreneurship as a process that involves 'innovative use and combination of resources to pursue opportunities to catalyze change and/or address social needs'. Similarly, Sargeant (2009) regards entrepreneurs as innovative and persuasive in attracting extra resources to achieve their goals. Given the use of innovation and entrepreneurialism is under-researched and has the potential to offer NPOs potential new streams of revenue and service delivery processes to benefit clients, two research questions are offered: 
RQ12: How do/can not-for-profit organizations better utilize innovation/entrepreneurialism to improve service delivery?

RQ13: How do/can NPOs better utilize innovation/entrepreneurialism to improve revenue generation?

\section{A For-profit : Controversies over definition and scope of market orientation}

There are at times debates as to the actual definition and scope of market orientation. Shapiro (1988) suggests that there are numerous similar terms mentioned in the literature such as 'market-oriented', ‘customer-oriented', 'market-driven' and 'customer-driven'. Whilst some researchers may use these terms interchangeably, others have suggested however, that there is a distinct difference between 'market-driven' and 'market-driving', albeit, both being approaches to market orientation. Slater and Narver (1998) point out that a 'customer-led' philosophy is concerned with satisfying the expressed needs of customers (and is relatively short term in focus), whereas a 'market orientation' also includes latent needs of customers and is thus longer term in focus. Slater and Narver (1998, p. 1003) also emphasise that 'market orientation is not a marketing orientation. Marketing is only a function of the business. A business is marketoriented only when the entire organisation' is involved. Whilst rigorous discussion of market orientation definitions occurred during the 1990’s, most current research regarding market orientation accepts the seminal definitions provided by Kohli and Jaworski (1990) as well as Narver and Slater (1990).

\section{B NPO : Controversies over definition and scope of market orientation}


Various definitions and frameworks of market orientation have been developed in the for-profit sector. Researchers have aimed to directly transfer these to the nonprofit sector or modified them to take into account perceived differences between the for-profit and nonprofit sectors. Frameworks offered by Sargeant, Foreman and Liao (2002), Gonzalez, Vijande and Casielles (2002) and more recently by Duque-Zuluaga and Schneider (2008) are the only market/societal orientation frameworks found during the systematic review of literature that specifically aim to offer a customised market/societal orientation model for the nonprofit sector (and can be regarded as adaptations of the Narver and Slater (1990) and Kohli and Jaworski (1990) for-profit models). Whilst these nonprofit frameworks provide a useful starting-point, these frameworks could be regarded as somewhat broad as they attempt to cover all sub-sectors of the nonprofit sector in a single framework. Thus it would be valuable to develop separate frameworks for each nonprofit sub-sector. This is a significant research opportunity. Thus, research into market/societal orientation within the nonprofit sector should be conducted at a more micro-level rather than the macro-level. This research could be progressed to further refine and develop appropriate definitions and frameworks of market orientation/societal orientation within the nonprofit sector and its sub-sectors.

RQ14: What is the appropriate definition of market orientation (or societal orientation) for each sub-sector of the nonprofit sector?

RQ15: What is the appropriate market orientation (or societal orientation) framework for each sub-sector of the nonprofit sector? 


\section{CONCLUSION}

Our systematic review of the market orientation literature shows that many research opportunities exist within the nonprofit sector to increase our knowledge regarding market orientation. We thus have developed and offer various research questions that academics, research students and practitioners may wish to consider as areas worth future attention with the aim of increasing our knowledge of market orientation within the nonprofit sector.

This paper offers a systematic review and synthesis of the literature regarding market orientation. The review of literature has identified how research of market orientation has developed into various aspects and themes. Definitions of market orientation were initially

discussed, followed by the wide range of aspects of market orientation including barriers and resistance to market orientation, organizational responsiveness to the environment, organizational factors and controversies.

The review has shown that market orientation has been widely researched within the forprofit sector but is under-researched within the nonprofit sector. Given the evidence that adopting a market orientation is associated with increased organizational performance within the for-profit sector and the belief that market orientation in some form is relevant to the nonprofit sector, managers within the nonprofit sector would benefit from increased research of market orientation within their sector, particularly given the key role the sector plays in society, and the current increased competition for revenue sources.

We live in an ever-changing world. Given the vital role that NPOs (particularly the charity sub-sector) play within the community to assist the wellbeing of society, increased research of market orientation within the nonprofit sector would be beneficial. We therefore 
issue a challenge to market orientation researchers to progress their research within the nonprofit sector - for the benefit of society.

\section{REFERENCES}

Ahmadi, M., \& Helms, M.M. (1997). Small firms, big opportunities: The potential of careers for business graduates in SMEs. Education and Training, 39, 52-57.

Andreasen, A.R., \& Kotler, P. (2003). Strategic Marketing for Nonprofit Organisations. 6th edn. Upper Saddle Creek, NJ: Prentice Hall.

Andreasen, AR and Kotler, P 2008, Strategic Marketing for Nonprofit Organisations, 7th edition, Pearson Education, London.

Anheier, H. (2000). Managing non-profit organisations: Towards a new approach. Civil Society Working Paper 1, January 2000. Retrieved from http://eprints.lse.ac.uk/29022/1/cswp1.p $\mathrm{df}$

Australian Bureau of Statistics. (2009). International Classification of Non Profit Organisations. Retrieved from http://www.abs.gov.au/ausstats/abs@.nsf/Latestproducts/5256.0Appendix 12006-07?opendocument\&tabname=Notes\&prodo=5256.0\&issue=2006-07\&num=\&vie $\mathrm{w}=$

Baker, W.E., \& Sinkula, J.M. (1999a). Learning orientation, market orientation, and innovation: Integrating and extending models of organisational performance. Journal of Market Focused Management, 4, 295-308.

Baker, W.E., \& Sinkula, J.M. (1999b). The synergistic effect of market orientation and learning orientation on organisational performance. Journal of the Academy of Marketing Science, 27, 411-427. 
Baker, W.E., \& Sinkula, J.M. (2002). Market orientation, learning orientation and product innovation: Delving into the organisation's black box. Journal of Market Focused Management, 5, 5-23.

Baker, W.E., \& Sinkula, J.M. (2005). Market orientation and the new product paradox. The Journal of Product Innovation Management, 22, 483.

Balabanis, G., Stables, R., \& Phillips, H. (1997). Market orientation in the top 200 British charity organisations and its impact on their performance. European Journal of Marketing, 31(8), 583-603.

Balser, D., \& McClusky, J. (2005). Managing stakeholder Relationships and Nonprofit Organization Effectiveness. Nonprofit Management \& Leadership. 15, 295-315.

Barrett, H., Balloun, J., \& Weinstein, A. (2005). Success factors for organisational performance: Comparing business services, health care, and education. SAM Advanced Management Journal, 70(4), 16-28.

Becherer, R.C., Halstead, D., \& Haynes, P. (2001). Marketing orientation in SME's: Effects of the internal environment. Journal of Research in Marketing \& Entrepreneurship, 3(1), pp. 1-17. Retrieved from http://webserv.ewu.edu/groups/cbpacea/2001SpringArticles/m arketingorientationinSMEsEffectsoftheinternalenvironment.pdf

Beckett, R.C. (2005). Collaboration now a strategic necessity. Handbook of Business Strategy, 6, 327-332.

Beverland, M., \& Lindgreen, A. (2007). Implementing market orientation in industrial firms: A multiple case study. Industrial Marketing Management, 36, 430-442. 
Bhaskaran, S. (2006). Incremental innovation and business performance: Small and medium size food enterprises in a concentrated industry environment. Journal of Small Business Management, 44, 64-80.

Bisp, S. (1999). Barriers to increased market-oriented activity: What the literature suggests. Journal of Market Focused Management, 4, 77-92.

Blankson, C. and Cheng, J. (2005). Have small businesses adopted the market orientation concept? The case of small businesses in Michigan. Journal of Business \& Industrial Marketing, 20, 317-330.

Blankson, C., \& Stokes, D. (2002). Marketing practices in the UK small business sector. Marketing Intelligence \& Planning, 20, 49-61.

Börjesson, S., \& Dahlsten, F. (2004). Management action in development market orientation: A report from a customer knowledge project at Volvo Cars. Journal of Change Management, 4(2), 141-154.

Brady, E., Brace-Govan, J., Brennan, L., \& Conduit, J. (2011). Market orientation and marketing in nonprofit organizations. Indications for fundraising from Victoria. International Journal of Nonprofit and Voluntary Sector Marketing, 16, 84-98.

Brindley, C., \& Ritchie, B. (2000). Undergraduates and small and medium-sized enterprises: opportunities for a symbiotic partnership? Education and Training, 42, 509-517.

Brady, E., \& Johnson, L. (1999). FONGOs, BONGOs and PONGOs: The Misapplication of Market Orientation in Not For Profit Organisations, ANZMAC 1999 Conference, Sydney: University of New South Wales. 
Cano, C., \& Sams, D. (2009). The importance of an internal marketing orientation in social services. International Journal of Nonprofit and Voluntary Sector Marketing, 14, 285295.

Carson, D.J. (1985). The evolution of marketing in small firms. European Journal of Marketing, 19(5), 7-16.

Carson, D.J. (1990). Some exploratory models for assessing small firms' marketing performance (A qualitative approach). European Journal of Marketing, 24(11), 5-52.

Carson, D.J., \& Gilmore, A. (2000). Marketing at the interface: Not "What" but "How". Journal of Marketing Theory and Practice, 8, 1-7.

Chad, P. (2010). A marketing discourse framework for charities. PhD Thesis, School of Management and Marketing, Wollongong, University of Wollongong.

Chad, P., Kyriazis, E, \& Motion, J. (2010). Introduction of market orientation into charities, easier said than done? ANZMAC 2010 Conference. Christchurch: University of Canterbury.

Chen, M., \& Hambrick, D.C. (1995). Speed, stealth, and selective attack: How small firms differ from large firms in competitive behaviour. Academy of Management Journal, 38, 453482.

Covin, J.G., \& Slevin, D.P. (1988). The influence of organisational structure on the utility of an entrepreneurial top management style. Journal of Management Studies, 25, 217-237.

Cravens, D.W., Piercy, N.F., \& Prentice, A. (2000). Developing market-driven product strategies. Journal of Product \& Brand Management, 9, 369-388.

Cromie, S. (1991). The problems experienced by young firms. International Small Business Journal, 9(3), 43-61. 
Darroch, J., \& McNaughton, R. (2003). Beyond market orientation: Knowledge management and the innovativeness of New Zealand firms. European Journal of Marketing, 37, 572-593.

Day, G.S. (1994). The capabilities of market-driven organisations. Journal of Marketing, 58, 3752.

Deshpande, R., \& Farley, J.U. (2004). Organisational culture, innovativeness and market orientation in Hong Kong five years after handover: What has changed? Journal of Global Marketing, 17, 53-73.

Deshpande, R., Farley, J.U., \& Webster Jr, F.E. (1993). Corporate culture, customer orientation and innovativeness in Japanese firms: A quadrad analysis. Journal of Marketing, 57, 2337.

Drucker, P.F. (1954). The Practice of Management. New York, NY: Perennial Library.

Duque-Zuluaga, L., \& Schneider, U. (2008). Market orientation and organisational performance in the nonprofit context: Exploring both concepts and the relationship between them. Journal of Nonprofit \& Public Sector Marketing, 19(2), 25-47.

Engelen, A., Brettel, M., \& Heinemann, F. (2010). The antecedents and consequences of a market orientation: The moderating role of organisational life cycles. Journal of Marketing Management, 26, 515-547.

Farrell, M.A. (2000). Developing a market-oriented learning organisation. Australian Journal of Management, 25(2), 201-208.

Fuller, P. (1994). Assessing marketing in small and medium-sized enterprises. European Journal of Marketing, 28(12), 34-49. 
Gainer, B., \& Padanyi, P. (2002). Applying the marketing concept to cultural organisations: An empirical study of the relationship between market orientation and performance. International Journal of Nonprofit and Voluntary Sector Marketing, 7, 182-193.

Gainer, B., \& Padanyi, P. (2005). The relationship between market-oriented activities and market-oriented culture: Implications for the development of market orientation in nonprofit service organisations. Journal of Business Research, 58, 854-862.

Gatignon, H., \& Xuereb, J. (1997). Strategic orientation of the firm and new product performance. Journal of Marketing Research, 34, 77-90.

Gebhardt, G., Carpenter, G., \& Sherry Jr, J. (2006). Creating a market orientation: A longitudinal, multifirm, grounded analysis of cultural transformation. Journal of Marketing, 70, 37-55.

Gilmore, A., Carson, D., \& Grant, K. (2001). SME marketing in practice. Marketing Intelligence \& Planning, 19, 6-11.

Gonzalez, L.I.A., Vijande, M.L., \& Casielles, R.V. (2002). The market orientation concept in the private nonprofit organisational domain. International Journal of Nonprofit and Voluntary Sector Marketing, 7, 55-67.

Grinstein, A. (2008). The relationships between market orientation and alternative strategic orientations. European Journal of Marketing 42(1/2): 115-134.

Guo, C., \& Acar, M. (2005). Collaboration among nonprofit organizations: Combining resource dependency theory, institutional, and network perspectives. Nonproft and Voluntary Sector Quarterly. 34, 340-361.,

Hansmann, H.B. (1980). The role of nonprofit enterprise. The Yale Law Journal, 89, 835-901. 
Harris, L.C. (1996). Cultural obstacles to market orientation. Journal of Marketing Practice, 2(4), 36-52.

Harris, L.C. (1998). Barriers to market orientation: The view from the shopfloor. Marketing Intelligence \& Planning, 16, 221-228.

Harris, L.C. (2000). The organisational barriers to developing market orientation. European Journal of Marketing, 34, 598-624.

Harris, L.C. (2002). Sabotaging market-oriented culture change: An exploration of resistance justifications and approaches. Journal of Marketing Theory and Practice, 10, 58-74.

Harris, L.C., \& Ogbonna, E. (2001). Leadership style and market orientation: An empirical study. European Journal of Marketing, 35, 744-764.

Harris, L.C., \& Piercy, N. (1999). Management behaviour and barriers to market orientation in retailing companies. The Journal of Services Marketing, 13, 113-131.

Harris, L.C., \& Watkins, P. (1998). The impediments to developing a market orientation: An exploratory study of small UK hotels. International Journal of Contemporary Hospitality Management, 10, 221-226.

Hogarth-Scott, S., Watson, K., \& Wilson, N. (1996). Do small businesses have to practice marketing to survive or grow? Marketing Intelligence \& Planning, 14, 6-18.

Homburg, C., \& Workman Jr, J. (2000). Fundamental changes in marketing organization: The movement toward a customer-focused organizational structure. Journal of the Academy of Marketing Science, 28, 459-478.

Javalgi, R.G., Martin, C.L., \& Young, R.B. (2006). Marketing research, market orientation and customer relationship management: A framework and implications for service providers. Journal of Services Marketing, 20, 12-23. 
Jaworski, B.J., Macinnis, D.J., \& Kohli, A.K. (2002). Generating competitive intelligence in organisations. Journal of Market Focused Management, 5, 279-307.

Jones, L. (2000). Market orientation - A case study of three UK opera companies. International Journal of Nonprofit and Voluntary Sector Marketing, 5, 348-364.

Kara, A., Spillan, J.E., \& DeShields Jr, O.W. (2004). An empirical investigation of the link between market orientation and business performance in non-profit service providers. Journal of Marketing Theory and Practice, 12, 59-72.

Kennedy, K., Goolsby, J., \& Arnould, E. (2003). Implementing a customer orientation: Extension of theory and application. Journal of Marketing, 67(4), 67-81.

Kinnell, M., \& MacDougall, J. (1997). Marketing in the Not-For-Profit Sector. Oxford: Butterworth-Heinemann.

Kippenberger, T. (1998). Barriers to market orientation - The myths and realities. The Antidote, 3(5), 12-15.

Kirca, A., Jayachandran, S., \& Bearden, W. (2005). Market orientation: A meta-analytic review and assessment of its antecedents and impact on performance. Journal of Marketing, 69(April), 24-41.

Kohli, A.K., \& Jaworski, B.J. (1990). Market orientation: The construct, research propositions, and managerial constructs. Journal of Marketing, 54(2), 1-18.

Kohli, A.K., Jaworski, B.J., \& Kumar, A. (1993). MARKOR: A measure of market orientation. Journal of Marketing Research, 30, 467-477.

Kolb, B 2008, Marketing Research For Non-Profit Community and Creative Organizations. Amsterdam: Elsevier. 
Kotler, P., \& Lee, N.R. (2009). Up and Out of Poverty: The Social Marketing Solution, Upper Saddle River, NJ: Wharton School Publishing.

Kumar, N., Scheer, L., \& Kotler, P. (2000). From market to market driving. European Journal of Marketing, 18(2), 129-141.

Kyriakopoulos, K., \& Moorman, C. (2004). Tradeoffs in marketing exploitation and exploration strategies: The overlooked role of market orientation. International Journal of Research in Marketing, 21, 219-240.

Lafferty, B.A., \& Hult, G.T.M. (2001). A synthesis of contemporary market orientation perspectives. European Journal of Marketing, 35(1/2), 92-109.

Lam, S.S.K., Kraus, F., \& Ahearne, M. (2010). The diffusion of market orientation throughout the organization: A social learning theory perspective. Journal of Marketing, 74(September), 61-79.

Langerak, F., Hultink, E.J., \& Robben, H.S.J. (2004a). The impact of market orientation, product advantage and launch proficiency of new product performance and organisational performance. The Journal of Product Innovation Management, 21, 79-94.

Langerak, F., Hultink, E.J., \& Robben, H.S.J. (2004b). The role of predevelopment activities in the relationship between market orientation and performance. $R \& D$ Management, 34, 295-309.

Levitt, T. (1960). Marketing myopia. Harvard Business Review, 38(4), 45-56.

Lewin, K. (1951). Field Theory in Social Science. New York, NY: Harper \& Row.

Lewis, J. (1995). The Voluntary Sector, the State and Social Work in Britain: The Charity Organisation Society/Family Welfare Association Since 1869. Brookfield, VT: Edward Elgar. 
Liao, M-N., Foreman, S., \& Sargeant, A. (2001). Market versus societal orientation in the nonprofit context. International Journal of Nonprofit and Voluntary Sector Marketing, 6, 254-268.

Lings, I.N., \& Greenley, G.E. (2005). Measuring internal market orientation. Journal of Service Research, 7, 290-305.

Liu, H. (1995). Market orientation and firm size: An empirical examination in UK firms. European Journal of Marketing, 29, 57-71.

Lovelock, C., Patterson, P., \& Walker, R. (2004). Services Marketing - An Asia-Pacific and Australian Perspective. 3rd edn. Frenchs Forest: Pearson.

Low, D.R. (2005). Market orientation, performance and the market environment; A study of Australian manufacturing SME's. ANZMAC 2005 Conference, Perth. Retrieved from http://anzmac2005.conf.edu.au/P rograms\&Papers/pdfs/17-Strategic/17-Low.pdf

Luksetich, W. (2008). Government funding and nonprofit organizations. Nonprofit \& Voluntary Sector Quarterly, 37, 434-442.

Macpherson, A., \& Jones, O. (2010). Editorial: Strategies for the development of International Journal of Management Reviews. International Journal of Management Reviews, 12, 107-113.

Mair, J., \& Marti, I. (2006). Social entrepreneurship research: A source of explanation, prediction and delight. Journal of World Business, 21, 36-44.

Martinsons, M., \& Hosley, S. (1993). Planning a strategic information system for a marketoriented non-profit organisation. Journal of Systems Management, 44(2), 14-41.

Mason, K., \& Harris, L.C. (2005). Pitfalls in evaluating market orientation; An exploration of executives' interpretations. Long Range Planning, 38, 373-391. 
Matear, S., Gray, B.J., \& Garrett, T. (2004). Market orientation, brand investment, new service development, market position and performance for service organisations. International Journal of Service Industry Management, 15, 284-301.

Matear, S., Osborne, P., Garrett, T., \& Gray, B.J. (2002). How does market orientation contribute to service firm performance? An examination of alternative mechanisms. European Journal of Marketing, 36, 1058-1075.

Matsuno, K., Mentzer, J.T., \& Ozsomer, A. (2002). The effects of entrepreneurial proclivity and market orientation on business performance. Journal of Marketing, 66(3), 18-32.

Mavondo, F.T., Chimhanzi, J., \& Stewart, J. (2005). Learning orientation and market orientation. European Journal of Marketing, 39, 1235-1263.

McGuinness, T., \& Morgan, R.E. (2005). The effect of market and learning orientation on strategy dynamics. European Journal of Marketing, 39, 1306-1326.

Modi, P., \& Mishra, D. (2010). Conceptualising market orientation in non-profit organisations: Definition, performance, and preliminary construction of a scale. Journal of Marketing Management, 5, 548-569.

Morris, M., Coombes, S., \& Schindehutte, M. (2007). Antecedents and outcomes of entreprenuerial and market orientations in a non-profit context: Theoretical and empirical insights. Journal of Leadership and Organizational Studies, 13(4), 12-38.

Moulton, S., \& Eckerd, A. (2012). Preserving the publicness of the nonprofit sector: Resources, roles, and public values. Nonprofit \& Voluntary Sector Quarterly, 41, 656-685.

Murray, J., Yong Gao, G., \& Kotabe, M. (2011). Market orientation and performance of export ventures: the process through marketing capabilities, and competitive advantages. Journal of the Academy of Marketing Science, 39, 252-269. 
Narver, J.C., \& Slater, S.F. (1990). The effect of a market orientation on business profitability. Journal of Marketing, 54(4), 20-35.

National Center For Charitable Statistics. (2010). Number of nonprofit organizations in the United States, 1999 - 2009. Retrieved from http://nccsdataweb.urban.org/PubApps/profil e1.php

Naude, P., Desai, J., \& Murphy, J. (2003). Identifying the determinants of internal marketing orientation. European Journal of Marketing, 37, 1205-1220.

Nonprofit Australia (2006). Nonprofit Australia Overview 2006. Retrieved from http://www.nonprofitaustralia.org.au/pdf/Nonprofit\%20Australia\%20\%20Overview\%202 006\%20LH.pdf

Nonprofit Australia (n.d.). Context and rationale for establishment of Nonprofit Australia. Retrieved from http://www.nonprofitaustralia.org.au/pdf/Context.pdf

Osborne, S.P., \& Murray, V. (2000). Collaboration between non-profit organizations in the provision of social services in Canada: Working together or falling apart?. International Journal of Public Sector Management. 13, 9 - 19.

Padanyi, P.S., \& Gainer, B. (2004). Market orientation in the nonprofit sector: Taking multiple constituencies into consideration. Journal of Marketing Theory and Practice, 12, 43-58.

Pelham, A.M. (2000). Market orientation and other potential influences on performance in small and medium-sized manufacturing firms. Journal of Small Business Management, 38, 4867.

Pelham, A.M., \& Wilson, D.T. (1996). A longitudinal study of the impact of market structure, firm structure, strategy, and market orientation culture on dimensions of small-firm performance. Journal of the Academy of Marketing Science, 24, 27-44. 
Perry, M., \& Shao, A. (2002). Market orientation and incumbent performance in dynamic market. European Journal of Marketing, 36, 1140-1153.

Rosenbaum, N. (1984). The competitive market model: Emerging strategy for non-profits. The Nonprofit Executive, July, 4-5.

Ruekert, R.W. (1992). Developing a market orientation: An organisational strategy perspective. International Journal of Research in Marketing, 9, 225-245.

Salamon, L.M. (1987). Of market failure, voluntary failure, and third-party government: Toward a theory of government-nonprofit relations in the modern welfare state. Nonprofit \& Voluntary Sector Quarterly, 16, 29-49.

Salamon, L.M., \& Sokolowski, S.W. (2006). Employment in America's charities: A profile. Retrieved from http://adm-cf.com/jhu/pdfs/NED_Bulletins/National/NEW_Bulletin26_E mplyinAmericasCharities_2006.pdf

Sargeant, A. (2009). Marketing Management for Nonprofit Organisations. 3rd edn. New York, NY: Oxford University Press.

Sargeant, A., Foreman, S., \& Liao, M-N. (2002). Operationalizing the marketing concept in the nonprofit sector. Journal of Nonprofit \& Public Sector Marketing, 10(2), 41-65.

Savitt, R. (2001). Understanding marketing development in the Czech Republic. European Journal of Marketing, 35, 1386-1397.

Sehorn, A. (1995). Market orientation, strategic orientation and performance in not-for-profit organisations. PhD Thesis, Arizona State University, USA.

Seymour, T., Gilbert, D., \& Kolsaker, A. (2006). Aspects of market orientation of English and Welsh charities. Journal of Nonprofit \& Public Sector Marketing, 16, 151-169.

Shapiro, B. (1988). What the hell is 'market oriented'? Harvard Business Review, 66(6), 119-125.

Shoham, A, Rose, G.M., \& Kropp, F. (2005). Market orientation and performance: A meta analysis. Marketing Intelligence and Planning, 23, 435-454. 
Silverman, L., \& Taliento, L. (2006). What business execs don't know - but should - about nonprofits. Stanford Social Innovation Review, Summer, 37-43. Retrieved from http://www.ssireview.org

Slater, S.F., \& Narver, J.C. (1998). Research notes and communications - Customer-led and market-oriented: Let's not confuse the two. Strategic Management Journal, 19, 10011006.

Smith, D. (1997). Small is beautiful but difficult: Towards cost-effective research for small business. Journal of the Market Research Society, 39, 273-291.

Sonfield, M.C. (1981). Can student consultants really help a small business? Journal of Small Business Management, 19(4), 3-9.

Tajeddini, K., Trueman, M., \& Larsen, G. (2006). Examining the effect of market orientation on innovativeness. Journal of Marketing Management, 22, 529-551.

Tang, Y., Wang, P. \& Zhang, Y. (2005). Market Strategy And Business Performance: The Case Of Small Firms In China, ANZMAC 2005 Conference, Perth. Retrieved from http://anzmac2005.conf.uwa/edu.au/Programs\&Papers/pdfs/21-Mktg-Asia/21-Tang.pdf

Terziovski, M. (2003). The relationship between networking practices and business excellence: A study of small to medium enterprises (SMEs). Measuring Business Excellence, 7(2), 78-92.

van Raaij, E., \& Stoelhorst, J. (2008), The implementation of a market orientation: A review and integration of the contributions to date. European Journal of Marketing, 42, 1265-1293.

Vázquez, R., Álvarez, L., \& Santos, M. (2002). Market orientation and social services in private non-profit organisations. European Journal of Marketing, 36, 1022-1046. 
Warnaby, G., \& Finney, J. (2005). Creating customer value in the not-for-profit sector: A case study of the British Library. International Journal of Nonprofit and Voluntary Sector Marketing, 10, 183-195.

Webster Jr, F.E. (1988). The rediscovery of the marketing concept. Business Horizons, 31(3), 2940.

Wijewardena, H., \& Cooray, S. (1995). Determinants of growth in small Japanese manufacturing firms: Survey evidence from Kobe. Journal of Small Business Management, 33, 87-92.

Wong, V., Saunders, J., \& Doyle, P. (1989). The barriers to achieving stronger market orientation in British companies: An exploratory study. 22nd Annual Conference Proceedings, Marketing Education Group, Glasgow Business School, 35-64.

Wood, V., Bhuian, S., \& Kiecker, P. (2000). Market orientation and organisational performance in not-for-profit hospitals. Journal of Business Research, 48, 213-226. 
Table 1. Intensity To Which Various Relevant Issues Have Been Addressed In Existing Literature.

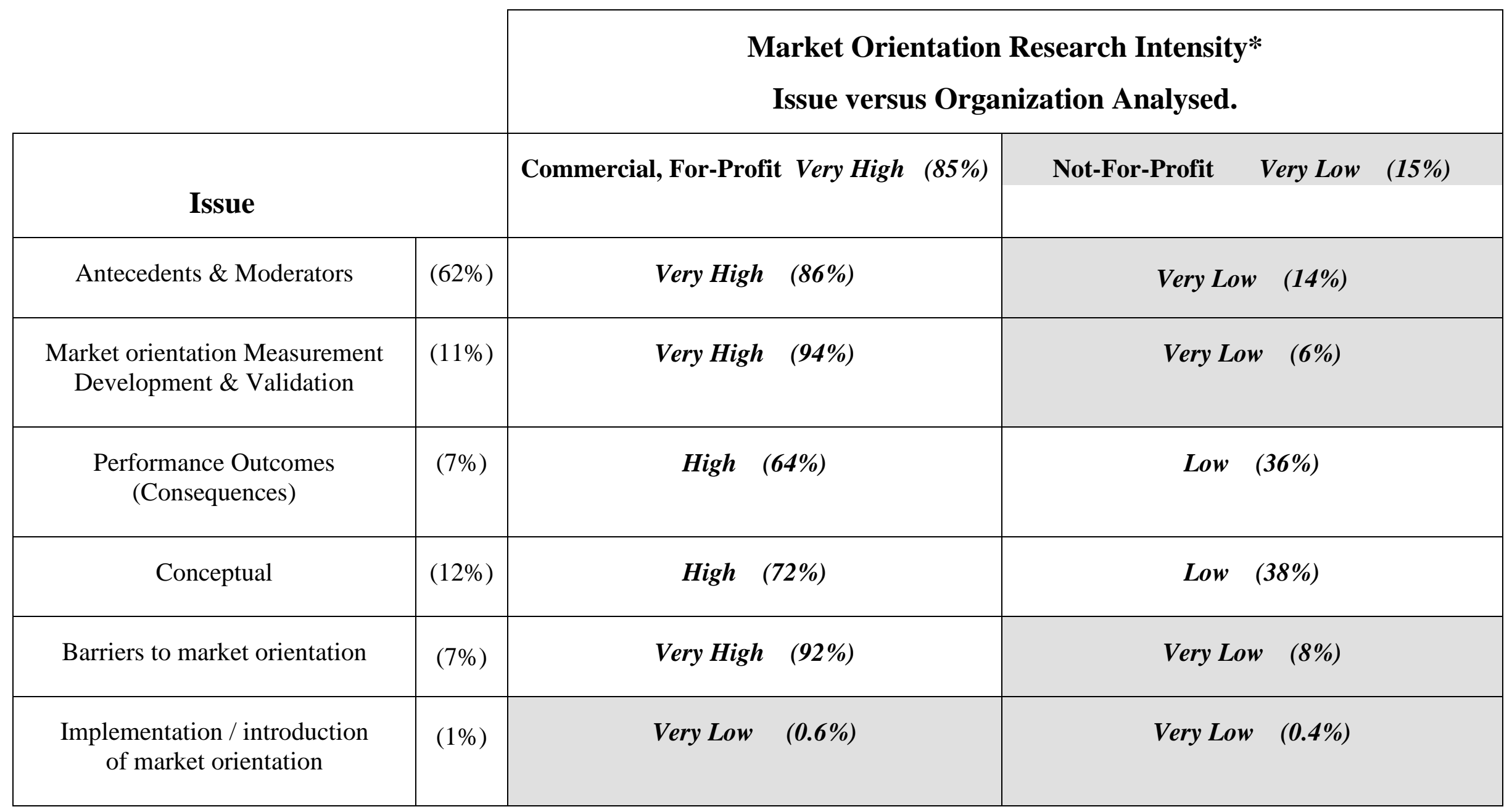

* Based upon count of number of relevant papers examined during our systematic Market Orientation literature review, converted to a percentage. Key: Very Low $=0-20 \% \quad$ Low $=21-40 \% \quad$ Medium $=41-60 \% \quad$ High $=61-80 \% \quad$ Very High $=81-100 \%$ 
Table 2. Key Differences Between For-Profit and Nonprofit Organizations.

\begin{tabular}{|c|c|c|}
\hline Characteristics & For profit & Not for Profit \\
\hline Objectives & Profit motive & Societal benefit \\
\hline Focus & Immediate customer satisfaction & Long-term society \\
\hline $\begin{array}{l}\text { Organizational } \\
\text { Culture }\end{array}$ & $\begin{array}{c}\text { Resource rich } \\
\text { Expenditure Seen as Investment }\end{array}$ & $\begin{array}{c}\text { Resource poor } \\
\text { Expenditure Seen as Cost }\end{array}$ \\
\hline Constituency & Customers & $\begin{array}{c}\text { Multiple } \\
\text { (Clients/Customers \& Donors) }\end{array}$ \\
\hline Marketplace & Competitive & $\begin{array}{l}\text { Competitive although collaborative } \\
\text { for some tendering and service } \\
\text { provision }\end{array}$ \\
\hline $\begin{array}{l}\text { Performance } \\
\text { Measurement }\end{array}$ & $\begin{array}{l}\text { Sales Revenue, ROI, Dividends, } \\
\text { Market Share }\end{array}$ & $\begin{array}{c}\text { Clients served, Client satisfaction, } \\
\text { Repeat donors }\end{array}$ \\
\hline Exchange & Money & $\begin{array}{c}\text { Often free, sometimes token } \\
\text { contribution, sometimes fee for } \\
\text { service }\end{array}$ \\
\hline $\begin{array}{c}\text { Senior } \\
\text { Management }\end{array}$ & $\begin{array}{c}\text { Business and Management Degree } \\
\text { qualified }\end{array}$ & $\begin{array}{l}\text { Traditionally based upon wealth of } \\
\text { industry experience }\end{array}$ \\
\hline Employees & Paid & Paid and volunteers \\
\hline Revenue & Sales & $\begin{array}{l}\text { Government, Fee for Service, } \\
\text { Donations/Fundraising }\end{array}$ \\
\hline Accountability & Shareholders & Board of Directors, Stakeholders \\
\hline Governance & Paid Board of Directors & Voluntary Board of Directors \\
\hline Product & Physical goods and Services & $\begin{array}{l}\text { Physical goods. Services including } \\
\text { emotional and informational support, } \\
\text { behavioural change }\end{array}$ \\
\hline Product Demand & Typically no large fluctuations & $\begin{array}{l}\text { Possible large fluctuations E,g. } \\
\text { disaster relief }\end{array}$ \\
\hline
\end{tabular}


